\title{
БЕЗПОСЕРЕДНІЙ ОБ' СКТ СКЛАДУ ЗЛОЧИНУ, ПЕРЕДБАЧЕНОГО СТ. 345 КК УКРАЇНИ
}

\section{КОНДРАТОВ Володимир Гарійович - здобувач Донецького юридичного інституту МВС України}

DOI:10.32782/NP.2020.1.20

УДК 343.533.9

У статті розглянуто питання шооо безпосереднъого об'єкту складу злочину, передбаченого ст. 345 КК Украӥни. Проаналізовано різні концепиї обєкта складу злочину. Досліджені питання основного та безпосереднъого обєкта складу злочину погрози або насильства щзодо працівника правоохоронного органу.

Обгрунтовано, що встановлення безпосереднього об'єкта злочину має важливе значення для з'ясування характеру $і$ ступеня суспільної небезпечності вчиненого злочину, правильної його кваліббікащії, дає можливість чітко розмежувати суміжні злочини.

Робиться висновок, що основний безпосередній об'єкт складу злочину являє собою найбільш важливі суспільні відносини, притаманні виключно даному складу злочину, характеризуе його істину природу та визначає місие конкретного складу злочину в структурі Особливої иастини КК України, перебувають під охороною конкретно визначеної кримінально-правової норми $і$ яким заподіюється або може заподіюватись шкода внаслідок вчинення певного злочину.

Основним безпосереднім об'єктом при вчиненні посягання на життя співробітника правоохоронного органу $є$ законна діяльність прачівника правоохоронного органу, додатковим безпосереднім об'єктом при скоєнні аналізованого посягання виступає життя зазначених осіб.

Подальшими напрямами наукових досліджень визначено проблематику співвід- ношення суспільних відносин 3 категорією інтересів та благ.

Ключові слова: правоохоронна діяльність, погроза, насильство, представник правоохоронного органу, об’єкт складу злочину.

На сучасному етапі становлення української держави чільне місце посідає питання виникнення, розвитку та вдосконалення іiі власної правової системи. В даному відношенні передову позицію займає одна 3 основних галузей права - кримінальне право. Завдання кримінального права полягає в охороні найважливіших суспільних відносин від злочинних посягань. Зокрема коло суспільних відносин, що знаходяться під кримінально-правовою охороною викладено в ст. 1 Кримінального кодексу України (далі - КК), яка носить назву „Завдання Кримінального кодексу України”, - це в першу чергу охорона прав і свобод людини і громадянина, власності, громадського порядку та громадської безпеки, довкілля, конституційного устрою України від злочинних посягань та забезпечення миру і безпеки людства, а також запобігання злочинам [2, с. 3].

Актуальність обраної проблематики полягає в тому, що протягом останнього десятиліття злочини, пов'язані 3 посяганнями на життя, здоров'я та власність працівників правоохоронних органів у зв'язку з виконанням ними службового обов'язку, а також їхніх близьких родичів набули ознак систем- 


\section{Кримінальне право, кримінальний процес та криміналістика}

ності, що власне і призвело до виникнення нагальної потреби поглибленого вивчення даного питання 3 метою вироблення спеціального механізму кримінально-правового захисту працівників правоохоронного органу та їх близьких родичів, придатного до реального застосування на практиці.

В теорії кримінального права проблема об'єкту складу злочину залишається однією 3 найбільш спірних. Науковці і досі не дійшли спільної думки щодо поняття об'єкту складу злочину, а так само і його складових частин. 3 цього приводу постійно точаться гострі дискусії, в яких народжуються все нові і нові трактування даного елементу складу злочину. Проте нас цікавить поняття саме безпосереднього об'єкта складу злочину, на основі якого ми зробимо спробу ідентифікувати ст. 345 КК України.

Встановлення безпосереднього об'єкта злочину має важливе значення для з'ясування характеру і ступеня суспільної небезпечності вчиненого злочину, правильної його кваліфікації, дає можливість чітко розмежувати суміжні злочини. Природу злочину найбільш повно відбивають ті конкретні суспільні відносини, які виступають безпосереднім об'єктом.

Протягом багатьох років дослідженням різних аспектів кримінально-правового захисту працівника правоохоронного органу від протиправних посягань у зв'язку 3 виконанням ним службового обов'язку та його близьких родичів займалось багато науковців, зокрема Ф.Н. Аббасов, Г.А. Агаєв, А.Ф. Бантишев, Н.І. Вєтров, В.Т. Дзюба, П.С. Єлізаров, І.Є. Ніконов, М.П. Журавльов, П.В. Замосковцев, С.М. Корабельников, В.М. Короленко, В.М. Мамчур, B.I. Осадчий, В.С. Плугатир, А.В. Савченко, М.М. Сенько, А.В. Терещенко, М.I. Хавронюк, Н.В. Шепелєва. Проте численні дослідницькі розробки досі не зняли всіх питань стосовно визначення безпосереднього об'єкту складу злочину, передбаченого ст. 345 КК України, а в наукових колах і надалі точаться гострі дискусії стосовно найбільш повного та точного визначення даного елементу складу злочину.

У зв'язку із цим, метою дослідження 6 встановлення безпосереднього обєкту скла- ду злочину погрози або насильства щодо працівника правоохоронного органу.

В теорії кримінального права його розуміють як конкретні суспільні відносини, поставлені законодавцем під охорону певної статті Особливої частини КК і яким завдається шкоди діянням, що підпадає під ознаки конкретного складу злочину [16, с. 99].

Розглядаючи даний аспект, А.В. Савченко визначає безпосередній об'єкт складу злочину як суспільні відносини, на які посягає конкретний злочин і яким він заподіює шкоду [3, с.82-84]. П.А. Фріс зазначає, що безпосередній об'єкт складу злочину - це конкретне суспільне відношення, благо або інтерес, на які посягає конкретний злочин [4, с.73]. П.С. Матишевський говорить, що під безпосереднім об'єктом складу злочину слід розуміти соціальні цінності, на які посягає конкретна злочинна дія або бездіяльність [5, с.103].

На нашу думку, вищевикладені твердження є в цілому правильними, проте найбільш повним та конкретизованим ми вважаємо визначення безпосереднього об'єкту складу злочину, яке дає В.Я. Тацій: „Це ті конкретні суспільні відносини, які поставлені законодавцем під охорону кримінального закону і яким завдається шкода злочином, що підпадає під ознаки даного складу", його ми і візьмемо за основу під час дослідження означеної проблематики [6, с.66].

Той факт, що законодавець відніс посягання на життя співробітника правоохоронного органу до числа злочинів проти авторитету органів державної влади, свідчить про основний безпосередній об'єкт злочину, хоча історія багата великим ілюстративним матеріалом, що свідчить про неоднозначність законодавчих рішень 3 приводу безпосереднього об'єкта аналізованого посягання.

Характеризуючи безпосередній об'єкт складу злочину, передбаченого ст. 345 КК „Погроза або насильство щодо працівника правоохоронного органу" хотілося 6 відзначити, що науковці-криміналісти розходяться в своїх судженнях стосовно необхідності існування такої кримінально-правової норми. На нашу думку, для того щоб правильно вирішити питання доцільності існування ст. 
345 КК слід звернути увагу на безпосередній основний та безпосередній додатковий об’єкти складу даного злочину.

Як слушно зазначає В.К. Грищук, безпосередній об'єкт складу злочину служить критерієм класифікації злочинів всередині кожного розділу Особливої частини КК України [7, с.80]. В юридичній літературі науковці поділяють безпосередній об'єкт складу злочину на основний та додатковий, останній, в свою чергу, ділиться на обов'язковий та факультативний. В даному відношенні погляди авторів щодо визначення основного та додаткового безпосереднього об'єкту складу злочину майже не розходяться.

Приміром, В.Б. Харченко основний безпосередній об'єкт складу злочину розуміє як найбільш важливі відносини, права, блага, свободи, цінності, що визначають місце складу злочину в структурі Особливої частини КК і охороняються конкретною кримінально-правовою нормою та яким заподіюється шкода, або які опиняються перед загрозою заподіяння шкоди внаслідок вчинення злочину. Додатковим же безпосереднім об'єктом складу злочину являються відносини, цінності, блага, права, свободи, яким шкода заподіюється завжди разом 3 основним при вчиненні даного конкретного злочину $[8$, с.36].

П.А. Фріс визначає основний безпосередній об’єкт складу злочину як такий, що визначає суспільну небезпеку конкретного діяння, входить в характеристику складу конкретного злочину та визначає його місце в системі родового та загального об'єктів складу злочину. Об'єкт складу злочину, якому в кожному випадку посягання на основний безпосередній об'єкт складу злочину обов'язково спричиняється шкода і який через це перебуває під кримінально-правовою охороною паралельно з основним безпосереднім об'єктом складу злочину носить назву додаткового безпосереднього об'єкту складу злочину [4, с.74].

Безперечно, жодне 3 наведених вище тверджень не можна ставити під сумнів, оскільки вони в цілому відображають істину природу основного та додаткового безпосереднього об'єкту складу злочину. Тим не менше ми вважаємо за доцільне внести певні уточнення у формулювання вказаних понять. Таким чином основний безпосередній об’єкт складу злочину нами вбачається як такий, що являє собою найбільш важливі суспільні відносини, притаманні виключно даному складу злочину, характеризує його істину природу та визначає місце конкретного складу злочину в структурі Особливої частини КК України, перебувають під охороною конкретно визначеної кримінально-правової норми і яким заподіюється або може заподіюватись шкода внаслідок вчинення певного злочину.

Що ж стосується злочину, передбаченого ст. 345 КК, а точніше визначення його безпосереднього об'єкта, то видається очевидним те, що даний злочин посягає одразу на декілька об'єктів. Шкода завдається як нормальній діяльності та авторитету правоохоронних органів, так і здоров'ю чи психічній недоторканості працівників правоохоронних органів або їх близьких родичів.

Подібні злочини, з-поміж яких і злочини, передбачені ст.ст. 346, 347, 348, 349, 350 КК, містять у собі декілька безпосередніх об'єктів, з яких законодавець обирає один, такий що за словами П.А. Фріса: „Виступає на «першу лінію» кримінально-правової охорони як найбільш важливий у випадку вчинення конкретного діяння", - той, який власне і визначає суспільну небезпеку даного злочину, структуру складу злочину, а інші охороняє паралельно в зв'язку з їх обов'язковим існуванням при вчиненні конкретного злочинного посягання [4, с.74]. Таким чином, можна пояснити існування самостійної кримінально-правової норми по захисту працівника правоохоронного органу та його близьких родичів від насильства або погрози вчиненням такого насильства.

Аналіз наукових праць, присвячених питанню безпосереднього об'єкта посягання па життя і здоров'я співробітника правоохоронного органу, показує, що серед учених немає єдиної точки зору з цього питання, хоча вони і сходяться в тому, що цей злочин $\epsilon$ многооб'ектним.

3 появою спеціального складу посягання на життя працівника міліції або народного дружинника у главі дев'ятій КК УРСР 1960 р. (ст. 191 (2)), в юридичній літературі 


\section{Кримінальне право, кримінальний процес та криміналістика}

велися численні дискусії з приводу віднесення цього злочину чи до злочиів проти життя, чи до злочинів проти порядку управління. Це було обумовлено тим, що неоднозначну оцінку серед вчених отримали саме основний і додатковий безпосередні об'єкти.

Більшість вчених вважали таке рішення цілком обгрунтованим. Наприклад, Н. I. Трофимов зазначав, що визнання за раніше діючим законодавством посягання на життя працівника міліції або народного дружинника у зв'язку з їх діяльністю по охороні громадського порядку злочином проти особистості нівелювало спрямованість зазначеного діяння проти порядку управління, його дійсну правову природу [17, с. 124].

Очевидно, що автор, аргументуючи свій висновок, віддавав перевагу соціально-політичного аспекту, відсуваючи на другий план аспект правовий. Певною мірою він ігнорував т принципові положення, що склалися в теорії кримінального права, що стосуються юридичної природи об'єкта, об'єктивної сторони складу злочину. Тому, в принципі, прийнятна точка зору не отримала достатнього обгрунтування i, природно, широкого визнання серед науковців і практиків.

Інші автори, наприклад П. П. Осіпов, стверджували протилежне i вважали, що включення посягання на життя працівника міліції в систему злочинів проти порядку управління навряд чи можна визнати обгрунтованим, тому що життя цих осіб як таке видається більш значущою, ніж порушення соціального управління в сфері охорони громадського порядку » [18, с. 460].

Суперечливість суджень 3 цього питання була викликана різним розумінням природи і характеру об'єкта, на заподіяння шкоди якому направлено вчинення аналізованого злочину: як було зазначено, воно передбачало посягання на два безпосередніх об'єкта на нормальну діяльність працівників міліції i народних дружинників і на життя цих осіб. Соціальної сутністю посягання на життя працівників міліції і народних дружинників, що знаходить своє юридичне вираження в розташуванні даного складу злочину в певному місці загальної системи кримінально-правових норм, є посягання на авторитет правоохоронних органів.
Дійсно, особа, що посягає на життя працівника поліції, прагне в першу чергу перервати або ускладнити його діяльність, а не просто заподіяти шкоду особі працівника поліції як такої. Тому суспільна небезпека аналізованого злочину полягає саме в тому, що він призводить до істотної дезорганізації правоохоронної діяльності, аж до ії повного припинення.

В юридичній літературі науковці майже одностайно визначають основний безпосередній об'єкт складу злочину, передбаченого ст. 345 КК, як нормальну діяльність та авторитет правоохоронних органів, які законодавець і прагнув поставити під кримінально-правову охорону, надаючи даним відносинам пріоритет перед додатковим безпосереднім об'єктом складу цього злочинy.

Так, наприклад, С. I. Дячук зазначає, що об'єктом злочину є такі складові авторитету правоохоронних органів, як особиста недоторканність та (або) законні майнові інтереси їх працівників та близьких родичів останніх, забезпеченням яких держава досягає необхідних умов для належного виконання такими працівниками своїх службових обов’ язків [19, с. 293].

На думку Л.П. Брич Основним безпосереднім об'єктом складу злочину, передбаченого ст.. 345 КК України, є нормальна діяльність правоохоронних органів, їх авторитет, а додатковим об'єктом - психічна недоторканність працівників правоохоронних органів або їх близьких родичів, їх здоров'я [20, с. 847].

I.M. Залялова зазначає, що основним безпосереднім об'єктом злочину, що передбачається ст. 345 КК є суспільні відносини, що забезпечують авторитет працівника правоохоронного органу. Додатковим об'єктом виступають суспільні відносини, що забезпечують особисту недоторканність працівника правоохоронного органу або його близьких родичів, а також їх здоров'я [21, с. 40].

Для прикладу зазначимо, що домінуючою думкою в кримінально-правовій літературі з приводу об'єкту посягання на життя співробітника правоохоронного органу $\epsilon$ судження про те, що таким може бути нор- 
мальна діяльність співробітників правоохоронних органів [22, с. 411$]$.

Що ж стосується додаткового безпосереднього об'єкту складу злочину, то на наше особисте переконання та думку інших на-

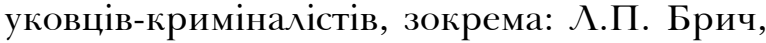
B.A. Клименка, B.I. Осадчого та інших, його зміст становлять суспільні відносини, що існують 3 приводу охорони здоров'я та психічної недоторканності працівника правоохоронного органу, а також його близьких родичів. Вочевидь, спираючись саме на додатковий безпосередній об'єкт складу злочину, передбаченого ст. 345 КК, деякі науковці роблять необгрунтовані, на нашу думку, припущення, стосовно недоцільності існування означеної норми як самостійного складу злочину. Окремі складові частини додаткового безпосереднього об'єкту складу злочину, передбаченого ст. 345 КК, є безпосередніми об'єктами складів злочинів, передбачених окремими кримінальноправовими нормами, а саме: ст.ст. 121, 122, 125, 126, 129, 195 КК - це, відповідно, умисне нанесення тяжких тілесних ушкоджень, умисне середньої тяжкості тілесне ушкодження, легке тілесне ушкодження, побої і мордування, погроза вбивством та погроза знищення майна. Проте, ще раз хотілося 6 акцентувати свою увагу саме на тому, що вказані суспільні відносини перебувають під кримінально-правовою охороною при вчиненні злочину, передбаченого ст. 345 КК, у зв'язку із тим, що їх порушення призводить до порушення суспільних відносин 3 приводу нормальної діяльності та авторитету правоохоронних органів, що і зумовлює існування даної самостійної статті Особливої частини КК України. Таке існування видається нам обгрунтованим і доцільним.

Таким чином, основним безпосереднім об'єктом при вчиненні посягання на життя співробітника правоохоронного органу є законна діяльність працівника правоохоронного органу, додатковим безпосереднім об'єктом при скоєнні аналізованого посягання виступає життя зазначених осіб.

На нашу думку, поняття безпосереднього об'єкту злочину слід сформулювати як суспільні відносини, інтереси та блага, що перебувають під кримінально-правовою охороною і яким у разі вчинення злочину заподіюється або може бути заподіяна шкода. Тим не менше ми аж ніяк не виключаємо можливості більш повного та точного визначення поняття об'єкта злочину. При подальших дослідженнях висвітленої проблематики особливу увагу варто звернути на те, що поряд із суспільними відносинами існують також інтереси та блага - це дозволить уникнути помилок, яких припускалися представники радянської школи кримінального права, коли закон швидше захищав існуючий лад, аніж інтереси та блага, необхідні для нормального існування особи.

\section{Аітература}

1. Конституція України // Відомості Верховної Ради України. - 1996. - № 30. C.T. 141.

2. Кримінальний кодекс України // К.: „ВЕАЕС”, 2005. - 152 с.

3. Кримінальне право України: Заг. частина: Підручник // Александров Ю.В., Антипов В.I., Володько М.В. та ін. // За ред. М.I. Мельника, В.А. Клименка. - К.: Юридична думка, 2004. - 352 с.

4. Фріс П.А. Кримінальне право України. Загальна частина: Підручник. - К.: Атака, 2004. - 488 с.

5. Матишевський П.С. Кримінальне право України: Загальна частина: Підручник. - К.: А.С.К., 2001. - 352 с.

6. Тацій В.Я. Об'єкт і предмет злочину в кримінальному праві України: Навч. посіб. - Харків: УкрЮА, 1994. - 76 с.

7. Грищук В.К. Загальний, родовий та безпосередні основні об'єкти злочинів проти життя і здоров'я людини // Вісник Аьвівського інституту внутрішніх справ: 36. наук. праць. - Аьвів: АIBC МВС України. 2002. - Вип. 1. - С. 77-88.

8. Харченко В.Б. Кримінальне право України. Загальна та Особлива частини у питаннях та відповідях. - К.: Атака, 2005. 272 c.

9. Грищук В.К., Ортинський В.А. До питання про поняття об'єкта злочину в сучасній науці кримінального права // Наукові записки Харківського економіко-правового університету. Серія право, економіка, гума- 
ністика: 36. наук. статей. - Харків: ХЕПУ. - 2004. - Вип. 1. - С. 30-38.

10. Науково-практичний коментар Кримінального кодексу України від 5 квітня 2001 року/ А.М. Бойко, А.П. Брич, В.К. Грищук, О.О. Дуров та ін.; За ред. М.I. Мельника, М.I. Хавронюка. - К.: Каннон, А.С.К., 2001. - 1104 c.

11. Науково-практичний коментар до Кримінального кодексу України / Ю.В. Александров, П.П. Андрушко, В.І. Антипов, В.А. Клименко та ін.; За ред. С.С. Яценка. К.: А.С.К., 2002. - 936 с.

12. Науково-практичний коментар Кримінального кодексу України: за станом законодавства та постанов Пленуму Верховного Суду України на 1 січня 1997 р. / За ред. В.Ф. Бойка, Я.Ю. Кондратьєва, С.С. Яценка. - К.: Юрінком, 1997. - 960 с.

13. Осадчий В. Відмежування заподіяння тілесних ушкоджень працівникові правоохоронного органу від суміжних посягань // Право України. - 1994. - № 3-4. - с. 24-26.

14. Хавронюк M.I. Довідник 3 Особливої частини Кримінального кодексу України. - К.: Істина, 2004. - 504 с.

15. Кримінальне право України. Особлива частина: Підручник // Ю.В. Александров, О.О. Дудоров, В.А. Клименко та ін. // За ред. М.І. Мельника, В.А. Клименка. - К.: Юридична думка, 2004. - 656 с.

16. Кримінальне право України: частина загальна. Підручник для студентів юрид. спец. вищ. закладів освіти /Бажанов М.І., Баулін Ю.В., Борисов В.І. та ін. /За ред. проф. М.І. Бажанова, В.В. Сташиса, В.Я. Тація. - Київ-Харків: Юрінком Інтер Право, 2002. - 416 c.

17. Трофимов Я. И. Квалификация отдельных видов тяжких преступлений: Учебное пособие. Иркутск, 1974. - 228 с.

18. Курс советского уголовного права. Часть Особенная [Учебник]. - $\Lambda .:$ Изд-во Ленингр. ун-та, 1978. - 558 с.

19. Науково-практичний коментар до Кримінального кодексу України : У 2 т. - Т. 2 / За заг. ред. П. П. Андрушка, В. Г. Гончаренка, Є. В. Фесенка. - 3-тє вид., перероб.

\section{SUMMARY}

The questions concerning the direct object of a crime under Art. 345 of the Criminal Code of Ukraine. Analyzed different concepts of object of a crime. Investigated the question of the primary and direct object of a crime or threat of violence against law enforcement officer.

It is substantiated that the establishment of the direct object of the crime is important for clarifying the nature and degree of public danger of the crime committed, its correct qualification, makes it possible to clearly distinguish between related crimes.

It is concluded that the main immediate object of the crime is the most important social relations inherent exclusively to this corpus delicti, characterizes its nature and determines the specific corpus delicti in the structure of the Special Part of the Criminal Code of Ukraine, is protected by a specific criminal law and which is caused or may be harmed as a result of a certain crime.

The main direct object in the commission of an attack on the life of a law enforcement officer is the lawful activity of a law enforcement officer, the additional direct object in the commission of the violation in question is the life of these individuals.

Further areas of research identified the problems of correlation of social relations with the category of interests and benefits.

Key words: law enforcement, threat, violence, law enforcement officer, the object of a crime.

та доп. - К. : Алерта, КНТ, Центр учбової літератури, 2009. - 624 с.

20. Науково-практичний коментар Кримінального кодексу України / Н34 За ред. М. І. Мельника, М. І. Хавронюка - 7-ме вид., переробл. та до- пов - К.: Юридична думка, 2010 - 1288 с.

21. Залялова І.М. Кримінальна відповідальність за втручання в діяльність працівника правоохоронного органу: дисертація на здобуття наукового ступеня кандидата юридичних наук за спеціальністю 12.00 .08 - кримінальне право та кримінологія; кримінально-виконавче право / Ірина Миколаївна Залялова. - К.: Академія адвокатури України, 2007. - 183 с.

22. Уголовное право России. Особенная часть [Учебник]. Под ред. А, И. Рарога. - М.: Изд-во «Триада, Атд», 1996. - 484 с. 